\title{
The $\alpha$-casein gene polymorphism of goats in tropical environment
}

\author{
M.T.A. Mohammed ${ }^{1} *$, J. M. Dhuha ${ }^{2}$, M.Z.H. Haniza ${ }^{3}$ and A. Al-Bakri Salih ${ }^{1}$ \\ ${ }^{1}$ Environmental Research Center, University of Technology, Baghdad 10001 - Iraq \\ ${ }^{2}$ Head Quarter, University of Anbar, Ramadi 54001 - Iraq \\ ${ }^{3}$ Department of Biology, Faculty of Science and Mathematics, Universiti Pendidikan Sultan Idris, \\ Tanjong Malim, Perak 35900 - Malaysia \\ *Corresponding E-mail:mmt198@gmail.com
}

Received April 02, 2019; Accepted August 20, 2019

\begin{abstract}
ABSTRAK
Penelitian ini diselesaikan untuk meneliti faktor bangsa yang mempengaruhi produksi susu pada dua bangsa kambing yang berbeda di daerah lingkungan tropis. Dua puluh delapan kambing yang merupakan bangsa asli digunakan dalam penelitian ini, yaitu Anglo-Nubian dan Saanen. Sampel darah diambil melalui pembuluh darah jugular, kemudian dimasukkan ke dalam tabung plastik tanpa EDTA untuk analisis polimorfisme gen. Perbedaan yang signifikan dalam berat molekul dan nilai frekuensi DNA antara keturunan dikaji dengan uji-t. Polimorfisme DNA yang ditemukan menunjukkan bahwa hanya alel $\mathrm{A}, \mathrm{B}$ dan $\mathrm{C}$ dari $\alpha$-kasein yang diidentifikasi pada semua sampel kedua bangsa kambing, sedangkan alel F ditemukan hanya pada kambing Saanen. Kesimpulan penelitian ini adalah kambing Saanen lebih beragam dalam alel $\alpha$-casein.
\end{abstract}

Kata kunci: polimorfisme, $\alpha$-casein, Anglo-Nubian, Saanen, kambing

\begin{abstract}
This study was completed to investigate the breed factor that influences milk production in different goat breeds in the tropical environmental area. A total of 28 goats were utilized in this work. These goats consisted of two different breeds, which were Anglo-Nubian and Saanen. Blood samples were withdrawn through jugular veins of goats into plastic tubes without EDTA for gene polymorphism. A t-test was used to analyse if there are any significant differences in molecular weight and frequency values of DNA between breeds. Investigation of DNA polymorphism in alleles $\mathrm{A}, \mathrm{B}$ and $\mathrm{C}$ of $\alpha$-casein were identified in all breeds, while allele $\mathrm{F}$ were studied in Saanen goats only. As a conclusion; Saanen goats have more varieties $\alpha$-casein allele

Keywords: gene polymorphism, $\alpha$-casein, Anglo-Nubian, Saanen, goat
\end{abstract}

\section{INTRODUCTION}

Examination of sub-atomic hereditary assorted variety is an effective supplement to assess phenotype and generation frameworks. It gives bits of knowledge into breed history; guides breed advancement and aids in basic protection leadership (Ajmone-Marsan et al., 2014).

Atomic information can be especially useful in distinguishing potential preservation holes when phenotypic learning is restricted. Likewise, hereditary portrayal has a remarkable job in Strategic Priority Area 1 of GPA on AnGR and structures an essential part in the advancement of 
national designs for the board of creature hereditary assets. Except for few investigations that portrayed atomic (proteins, microsatellite, and so forth.) (Wei et al., 2014) and extra-nuclear (mitochondrial) (Joshi et al., 2004) decent hereditary variety of chose Asian goat populaces, most original goat types of Asia remain to a great extent uncharacterized.

Another input and element in knowing the value of breeds are to study the genetic variety by the determination of genetic variability, which is through polymorphism. Polymorphism in a population emphasises a pool of genetic variability, for if none exists, there would be no advance made through selection and breeding. This accentuates the need to study polymorphism among breeds as well as within breeds. Polymorphism studies can be assumed at various levels and expressed protein studies to the genetic level studies (Groselande et al., 1990).

The adaptable innate ability of indigenous goats is principal in biological systems where brutal and extraordinary creation conditions are compounded by atmosphere changes as experienced in tropical creating nations (Mohammed, 2017).

Therefore, this study was designed to assess the distinctions between two diverse goat breeds (Anglo-Nubian and Saanen) in relation to gene polymorphism, with the effect of the breed.

\section{MATERIAL AND METHODS}

A total of 28 adult goats were used (Table 1). The goats belong to two breeds; namely, AngloNubian and Saanen.

\section{Animals}

A total of 28 goats were used. The goats belong to two breeds; namely, Anglo-Nubian ( $\mathrm{n}=$ $14)$, and Saanen $(\mathrm{n}=14)$. The age of the goats was one year up to two years old. Before the start of the experiment, the animals were fed and handled by research workers for two weeks to

Table 1. The Number of Sample Used

\begin{tabular}{lc}
\hline Breed of Goat & Number of Sample (head) \\
\hline Anglo-Nubian & 14 \\
Saanen & 14 \\
\hline
\end{tabular}

avoid any kind of stress (Mohammed et al., 2019).

\section{Gene Polymorphism}

A total of 28 blood serum samples were used for DNA extraction and Polymerase Chain Reaction (PCR) in order to prepare a casein gene. Blood samples: Blood tests were gathered from goats of different breeds. The blood was withdrawn through their jugular veins with a syringe with an $18 \mathrm{G}$ needle (Mohammed et al., 2018). The blood samples of $3.5 \mathrm{ml}$ were collected into plastic tubes without EDTA for serum separation.

\section{Genomic DNA Extraction}

The DNA extraction had been done using GeneJET Whole Blood Genomic DNA Purification Mini Kit (Thermo Fisher Scientific Inc., Lithuania, 2016), as per instruction. The purified DNA was used immediately in downstream applications using Image scanning (BIO-RAD, USA) then put away at $-20^{\circ} \mathrm{C}$ for PCR purpose.

\section{Polymerase Chain Reaction (PCR)}

The PCR amplification using eight different primers (Mohammed, 2017) as presented in Table 2 was completed in a $50 \mathrm{~mL}$ response blend comprising of $1 \mu \mathrm{L}$ genomic DNA, $10 \mu \mathrm{L}$ DDH2O, $10 \mu \mathrm{L}$ Master Mix and 20 pmol of the particular introductions for every allele. Warm cycling conditions were as pursue as; denaturation venture of $95^{\circ} \mathrm{C}$ for $4 \mathrm{~min}$, trailed by 32 cycles of $95^{\circ} \mathrm{C}$ for $30 \mathrm{~s}, 60^{\circ} \mathrm{C}$ for $30 \mathrm{~s}, 72^{\circ} \mathrm{C}$ for $2 \mathrm{~min}$ and the last expansion at $72^{\circ} \mathrm{C}$ for a $2 \mathrm{~min}$. The PCR items were exposed to electrophoresis on a $2 \%$ agarose gel and recoloured with ethidium bromide. The Image Lab Software of the Gel Documentation System (version 5.2.1, Bio-Rad, USA) was used to visualise the presence of DNA fragment according to size.

Analysis of gene polymorphism: Information examination was performed utilizing the IBM SPSS software program (version 22.0 for Mac). All values were expressed as mean, standard division, and standard error mean.

The t-test (Levene's test for equality of variances) were done with SPSS. Significance utilized was $\mathrm{P}<0.001$. The examination decided the critical contrasts dependent on the gene polymorphism, which were affected by breed kind of the goats. 


\section{RESULTS AND DISCUSSION}

\section{Gene Polymorphism}

Table 3 demonstrates the descriptive statistics of 28 samples from different breeds of goats that have been used in this study. Six alleles of as 1-Casein were included; such as A, B, C, D, $\mathrm{E}$, and F. Alleles A, B, C and F were detected. In addition, results showed different results among breeds regarding allele type. However, alleles A, $\mathrm{B}$, and $\mathrm{C}$ were detected in both types. While allele

Table 2. The List of Primers Used in the PCR Mixed

\begin{tabular}{ll}
\hline System & Primer \\
\hline
\end{tabular}

A3-O1 BT33 5' '-gatattgggagtgaatcaactgag-3'

BT66 5'-ctcacttgacgaactgcttccagc-3'

A2-O BT25 5' '-gaagatgtgccetctgagcgttac-3'

BT60 5'-ctctttcatactgtgaagttgttc-3'

System 3 BT51 5'-gagaacatcaatgaactgatgaag-3'

BT32 5'-cagctggggcacgttgtatttttcag-3'

System 5 BT25 5' -gaagatgtgccetctgagctgtac-3'

BT74 5'-cagatggggcacgttgtatttttcag-3'

B3-C BT66 5' -actcactggagagagtccttggat-3'

BT97 5'-gtggctgttgctcttgccaggcc-3'

A0-A1-D BT65 5'-ctcagggtagaagtaggccag-3'

BT36 5'-gaacaacttcacagtatgaaagag-3'

Allele E BT99 5'-ctatcatgtcaaaccattctatcc-3'

BT72 5' - caatttcacttaaggatgttacac-3'

Allele F BT58 5'-aagtttcatggttgtcaagat-3'

BT73 5'-gaattccttgatcatcaacccagc-3'
F were distinguished just in Saanen goats. Moreover, alleles D and E did not detect in both breeds.

\section{Molecular Weight Value}

Table 4 shows the descriptive statistics of molecular weight values of as1-Casein alleles from different breeds of goats that have been analysed. In general, the total mean value of MW of allele $\mathrm{C}$ was higher compared to alleles $\mathrm{A}$ and B. Allele B was higher in Anglo-Nubian compared to Saanen. Moreover, allele F was detected only in Saanen goats.

T-test was led to affirm whether there is any noteworthy distinction between goat breeds on the gene polymorphism value. Results were showed there was no huge contrast $(\mathrm{P}>0.001)$ on alleles types among breeds of goats.

\section{Frequency of as1-casein Alleles}

Table 5 shows the descriptive statistics of frequency values from different breeds of goats that have been analysed in this study. Alleles A, B, and $\mathrm{C}$ were higher in Saanen goats compared to Anglo-Nubian. However, the frequency of allele F was only detected in Saanen goats.

T-test was directed to affirm whether there is any noteworthy distinction between breeds of adult goats on the frequency per cent of gene polymorphism. Results appeared there was no critical distinction $(\mathrm{P}>0.001)$ on alleles between goat breeds.

Goat hereditary examinations are still in their earliest stages, and just a couple of studies exploring decent hereditary variety, phenotypegenotype affiliation, and marks of choice are accessible (Lashmar et al., 2016; Mdladla et al., 2016). None of these investigations surveyed the genomic adjustment to explicit conditions nor endeavoured to unwind the environmental significance of the genome-wide exception markers. The versatile hereditary capability of original breeds is vital in biological communities

Table 3. Gene Polymorphism Detecting of Different Breeds of Adult Goats

\begin{tabular}{|c|c|c|c|c|c|c|}
\hline \multirow{2}{*}{ Breed } & \multicolumn{6}{|c|}{ Allele } \\
\hline & $\mathrm{A}$ & $\mathrm{B}$ & $\mathrm{C}$ & $\mathrm{D}$ & $\mathrm{E}$ & $\mathrm{F}$ \\
\hline Anglo-Nubian $(\mathrm{n}=14)$ & $\sqrt{ }$ & $\sqrt{ }$ & $\sqrt{ }$ & $\mathrm{X}$ & $\mathrm{X}$ & $\mathrm{X}$ \\
\hline Saanen $(n=14)$ & $\sqrt{ }$ & $\sqrt{ }$ & $\sqrt{ }$ & $X$ & $\mathrm{X}$ & $\sqrt{ }$ \\
\hline
\end{tabular}


Table 4. Molecular Weight Value (Kilodaltons) of Goats

\begin{tabular}{|c|c|c|}
\hline Allele & Breed & Mean \pm SD \\
\hline \multirow[t]{2}{*}{ Allele A } & Anglo-Nubian $(\mathrm{n}=14)$ & $38.47 \pm 72.52$ \\
\hline & Saanen $(\mathrm{n}=14)$ & $40.26 \pm 64.59$ \\
\hline \multirow[t]{2}{*}{ Allele B } & Anglo-Nubian $(\mathrm{n}=14)$ & $71.44 \pm 98.23$ \\
\hline & Saanen $(\mathrm{n}=14)$ & $29.16 \pm 28.74$ \\
\hline \multirow[t]{2}{*}{ Allele C } & Anglo-Nubian $(\mathrm{n}=14)$ & $112.16 \pm 98.89$ \\
\hline & Saanen $(\mathrm{n}=14)$ & $100.81 \pm 96.40$ \\
\hline \multirow[t]{2}{*}{ Allele } & Anglo-Nubian $(\mathrm{n}=14)$ & $0.00 \pm 0.00$ \\
\hline & Saanen $(\mathrm{n}=14)$ & $110.18 \pm 89.66$ \\
\hline
\end{tabular}

Table 5. Frequency Value (\%) of Goat Breed

\begin{tabular}{clc}
\hline \multicolumn{1}{c}{ Allele } & \multicolumn{1}{c}{ Breed } & Frequency \pm SD \\
\hline Allele A & Anglo-Nubian $(\mathrm{n}=14)$ & $62.75 \pm 33.93$ \\
& Saanen $(\mathrm{n}=14)$ & $66.51 \pm 29.20$ \\
Allele B & Anglo-Nubian $(\mathrm{n}=14)$ & $51.87 \pm 39.40$ \\
& Saanen $(\mathrm{n}=14)$ & $69.33 \pm 26.12$ \\
Allele C & Anglo-Nubian $(\mathrm{n}=14)$ & $27.77 \pm 30.34$ \\
& Saanen $(\mathrm{n}=14)$ & $39.62 \pm 19.20$ \\
Allele F & Anglo-Nubian $(\mathrm{n}=14)$ & $0.00 \pm 0.00$ \\
& Saanen $(\mathrm{n}=14)$ & $21.92 \pm 36.19$ \\
\hline
\end{tabular}

where brutal and extraordinary generation conditions are intensified by atmosphere Progressions as encountered in tropical developing countries.

The prominent proof of the as1-casein quality, genotyping was restricted to the $\mathrm{A}, \mathrm{B}$ and $\mathrm{C}$ alleles which were discovered altogether more anyway much as could sensibly be normal in all of the animals. The $\mathrm{D}$ and $\mathrm{E}$ alleles were not perceived in a wide scope of the goat, while $\mathrm{F}$ allele was found in Saanen goats. The repeat of as1-casein; An and B alleles were seen to be higher in Saanen goats. That closeness of secondary repeatable of as1-casein in the goats exhibits their capability will aggravate milk holding secondary as1-casein protein. However, the results were close to those reported by Mohammed (2017) and higher than those revealed by Amie Marini et al. (2011). These variations maybe because of the differences of goat breeds. However, within the breed, genetic improvement of these traits is possible (Taylor et al., 2016); for example, reproductive and health genetic merit of Holstein cows has slightly increased in the past ten years (Berry et al., 2014).

Concerning the varieties watched for every casein allele, there is hard to translate the immense writing identified with the subject and contrast them and present outcomes. Moreover, these discoveries bolster the capability of versatile 
limit appeared by goats (Lopez-Exposito and Recio, 2006), which might be persuasive develop the likeness between the casein profiles from the diverse goat breeds utilized as a part of this research.

The high recurrence of the solid genotypes can be connected with the age of milk with high fat and protein content and with perfect mechanical properties. In reality, clear and vital contrasts were found in the cheddar yield with $+7.4 \%$ among AA and EE alleles, and $+14.8 \%$ among allele AA and allele FF alleles (Grosclaude and Martin, 1997). Additionally, casein centre is progressively unmistakable when solid alleles are accessible (Martin et al., 2002). Maga et al. (2009), in a survey on the as1-casein content in American dairy goats, using sodium dodecyl sulfate-polyacrylamide gel electrophoresis and two-dimensional gels, exhibited that milk from FF and EE alleles animals had 35 and 25\% fewer caseins, independently than creatures homozygous for the solid alleles. The nearness of A or B allele in heterozygote condition with either the $\mathrm{F}$ or $\mathrm{E}$ allele decreased the lack in casein by just $5-7 \%$ distinction and AA homozygote condition.

The secondary repeat of the robust genotypes could be joined with the Agdistis of the drain with helter-skelter fat what is more protein substance furthermore with immaculate mechanical properties. Over reality, clear and crucial contrasts were discovered in the cheddar yield with $+7.4 \%$ "around AA Also ee alleles, Furthermore $+14.8 \%$ around allele AA and allele FF alleles (Grosclaude and Martian, 1997). Additionally, casein focal point will be progressively unmistakable at strong alleles are open (Martin et al., 2002). Maga et al. (2009), for an overview of the as1-casein content to American dairy goats, utilising sodium dodecyl sulfate-polyacrylamide gel electrophoresis what is more two-dimensional gels, exhibited that milk from $\mathrm{FF}$ and ee alleles animals required 35 Also $25 \%$ Lesquerella caseins, independently, over animals homozygous to the strong alleles. That closeness about $\mathrm{a}$ or $\mathrm{b}$ allele to heterozygote state for whichever the falternately e allele diminished that absence for casein by simply $5-7 \%$ qualification Furthermore AA homozygote state.

\section{CONCLUSION}

The milk from Saanen goats has better proportions of casein when appeared differently in relation to the milk from different goats; this could likewise be seen toward taking a gander at those power of the get-togethers identified with the caseins in the electrophoretic profiles.

\section{ACKNOWLEDGEMENT}

The authors would like to acknowledge the invaluable contribution of the Environmental Research Center, University of Technology, Iraq in supporting this work.

\section{REFERENCES}

Ajmone-Marsan, P., L. Colli, J.L. Han, A. Achilli, H. Lancioni, S. Joost, P. Crepaldi, F. Pilla, A. Stella, P. Taberlet, P. Boettcher, R. Negrini, J.A. Lenstra, Italian Goat Consortium Econogene, Globaldiv and Consortium. 2014. The characterization of goat genetic diversity: Towards a genomic approach. Small Rum. Res. 121(1):58-72.

Amie Marini, A.B., B. Abdul Rashid, K. Musaddin and I. Zawawi. 2011. as1-Casein gene polymorphism in Katjang, Jamnapari, Boer and Boer-feral goats in Malaysia. J. Trop. Agric. 39(1):1-5.

Berry, D.P., E. Wall and J.E. Pryce. 2014. Genetics and genomics of reproductive performance in dairy and beef cattle. Animal. 8(1):105-121.

Grosclaude, F. and P. Martin. 1997. Casein polymorphisms in the goat. In 'Proceedings of International Dairy Federation milk protein polymorphism seminar II'. pp. 241-253. (International Dairy Federation: Bruxelles, Belgium).

Groselande, F., R.Y. Aupetit, J. Leebvere and J.G. Merioux. 1990. Essai d'analysis of genetic elasticities between French cattle breeds with biochemical polymorphism. Genet. Sel. Evol. 22:317-318. 318.

Joshi, M.B., P.K. Rout, A.K. Mandal, C. TylerSmith, L. Singh and K. Thangaraj. 2004. Phylogeography and origin of Indian domestic goats. Mol. Biol. Evol. 21(3):454462.

Lashmar, S.F., C. Visser and E. van Marle-Köster. 2016. SNP-based genetic diversity of South African commercial dairy and fiber goat breeds. Small Rum. Res. 136(1):65-71.

Lopez-Exposito, I. and I. Recio. 2006. Antibacterial activity of peptides and folding variants from milk proteins. Int. Dairy J. 16(11):1294-1305. 
Maga, E.A., P. Daftari, D. Kultz and M.C.T. Penedo. 2009. Prevalence of as1-casein genotypes in American dairy goats. J. Animal Sci. 87(11):3464-3469.

Martin, P., M. Szymanowska, L. Zwierzchowski and C. Leroux. 2002. The impact of genetic polymorphisms on the protein composition of ruminant milks. Reprod. Nutr. Dev. 42:433-459.

Mdladla, K., E.F. Dzomba, H. Huson and F.C. Muchadeyi. 2016. Population genomic structure and linkage disequilibrium analysis of South African goat breeds using genome-wide SNP data. Anim. Genet. 47(4):471-482.

Mohammed, Muayad TA. 2017. Factors influencing the productive performance of selected goat breeding systems in Malaysia. Thesis submitted in fulfillment of the requirement for the degree of doctor of philosophy (biology). Faculty of science and mathematics, Sultan Idris Education University.
Mohammed, Muayad TA, M.Z.H. Haniza and I. Husni. 2019. Reproductive performance of different goat breeds in Malaysia. Indian J. Anim. Res. 53(1):24-27.

Mohammed, Muayad TA, M.Z.H. Haniza, I. Husni and Alene Tawang. 2018. Hematological values of apparently healthy indigenous goats in Malaysia: A comparative study. Indian J. Anim. Res. 52(12):1701-1704.

Taylor, J.F., K.H. Taylor and E.D. Decker. 2016. Holstein are the genomic selection poster cows. Proceedings of the National Academy of Sciences USA 113(28):7690 7692.

Wei, C., J. Lu, L. Xu, G. Liu, Z. Wang, F. Zhao, L. Zhang, Xu. Han, L. Du and C. Liu. 2014. Genetic structure of Chinese indigenous goats and the special geographic structure in the southwest China as a geographic barrier driving the fragmentation of a large population. PLoS One 9(4):e94435. 